Research Article

Iván Igartua*, Ekaitz Santazilia

\title{
How Animacy and Natural Gender Constrain Morphological Complexity: Evidence from Diachrony
}

https://doi.org/10.1515/opli-2018-0022

Received October 31, 2017; accepted June 15, 2018

Abstract: In addition to its central role in the organization of gender systems and its numerous effects on different parts of the grammar, animacy reveals itself as a significant, sometimes even determinant factor in diachronic processes like the reduction of morphological complexity. Complexity in the realm of inflection may be defined as the extent to which formal distinctions in paradigms are semantically or phonologically unmotivated and therefore largely unpredictable on extramorphological grounds. Animacy and natural (or sex-based) gender emerge in certain cases as features capable of constraining this kind of complexity by offering a transparent semantic criterion that helps substantiate several formal distinctions in languages, thereby reducing the amount of morphological complexity or unpredictability inherited from earlier stages in the evolution of different linguistic systems.

Keywords: Animacy, natural gender, morphological complexity, allomorphy, diachronic change, marginal gender, gender loss.

\section{Introduction: Animacy in gender systems and beyond}

Animacy is a semantic feature multifariously expressed in languages, with asymmetries based on animacy affecting various grammatical levels and linguistic categorization devices. Even though a complete taxonomy of animacy-based effects encompassing all the grammatical phenomena associated with this feature is still lacking, there has been solid typological research on this matter (Comrie 1989: 185-200, Ortmann 1998, Dahl \& Fraurud 1996, Dahl 2000a, Malchukov 2008, Kittilä, Västi \& Ylikoski 2011, de Swart \& de Hoop 2018). One area that has received particular attention is that of inflectional morphology, where one can find various kinds of marking asymmetries that depend on animacy. On the one hand, some languages make use of special affixes in certain morphological cases to express the semantic opposition between animate and inanimate nouns (or between human and non-human nouns). This is true of Basque, for example (see Santazilia 2013: 227), as illustrated in Table 1, in which several forms belonging to the animate paradigm are characterized by a distinctive marker - gan $-:^{1}$

1 Some of the case endings represented in the paradigm show allomorphic variation (ABL -dik/-tik and ALL - $a$ /-ra). Note also that the stem in several case forms includes the affixed article - $a$ - (as in the Loc seme- $a$-gan), but this is not always the case (cf. ohetik, ohera). Forms like the LOC, ABL and ALL can also be built on the genitive: cf. loc seme-a-ren-gan .

Article note: This paper belongs to the special issue on Effects of Animacy in Grammar and Cognition, edited by Diane Nelson and Virve Vihman.

*Corresponding author: Iván Igartua, University of the Basque Country, UPV/EHU, E-mail: ivan.igartua@ehu.eus Ekaitz Santazilia, Public University of Navarre 
Table 1. Basque singular noun declension (partial paradigms)

\begin{tabular}{lll}
\hline & Animate & Inanimate \\
\hline ERG & semea-k & ohea-k \\
GEN & semea-ren & ohea-ren \\
LOC & semea-gan & ohea-n \\
ABL & semea-gan-dik & ohe-tik \\
ALL & semea-gan-a & ohe-ra \\
& 'son' & 'bed' \\
\hline
\end{tabular}

In contrast to some cases like the ergative and the genitive, which show no differences between the paradigms, the locative, ablative, and allative exhibit rather different morphological structures in the animate and the inanimate paradigms.

On the other hand, as is the case in the majority of the Slavic languages, there are morphological systems characterized by diverging patterns of case syncretism, which crucially depend on the animacy of the referent. Other grammatical components that are usually subject to the influence of animacy include the expression of nominal number (Corbett 2000), noun classifier systems (Aikhenvald 2000), and verb inflection (Comrie 1989: 191-194).

Animacy is also commonly involved in gender systems (Dahl 2000b). In many languages, animacy lies at the basis of nominal classification or is at least one of several criteria for the distribution of nouns into different classes (following Dahl, we can consider it to be the principal 'building block' of gender systems). ${ }^{2}$ There are well-known examples of animacy-based gender in Australian, Caucasian, Dravidian, and North American languages, for example (Corbett 1991: 7-32).

Of course, a number of insights regarding the influence of animacy on grammar come from history (see now Cristofaro 2013), and this will be precisely the position taken in this article. The development of animacy in different languages commonly shows a tight interplay of semantic and formal factors. In the Slavic languages, grammatical animacy - primarily the accusative-genitive syncretism in noun paradigms is usually held to be subordinate to gender (it is in fact usually defined as a subgender, cf. Corbett 1991: 42), ${ }^{3}$ but other factors - such as the preexisting syncretism between the nominative and accusative cases or inflectional class membership - are involved as well (for a historical survey, see Klenin 1983, Krys`ko 1994). Additionally, the changing manifestation of the feature demonstrates that it may occasionally go beyond its original, well-established limits (affecting, for instance, genders other than the masculine, cf. Igartua $2009,2015)$, and analogy plays a role in this kind of secondary innovation. Conversely, animacy seems to be restricted in certain constructions in which one would expect its presence (this is the case in certain Russian numeral phrases when they are in direct object position or preceded by a preposition, see Mel'chuk 1980, Mikaelian 2013, Igartua \& Madariaga 2018). On a prototype-theoretical account (in the classic sense of Lakoff 1987), animacy can thus be viewed as a radial category that exhibits gradual realization depending on several factors.

In any case, our aim in this paper is to analyse the effects of animacy (and, secondarily, of natural or sex-based gender) on morphological complexity, defined as the extent to which formal differences in inflectional paradigms are semantically or phonologically unmotivated and therefore largely unpredictable

2 Animacy can be regarded both as a binary feature [ \pm animate] and as a continuum or scale ranging from more animate to less animate entities in which the cut-off point between them is not always straightforward (for examples and theoretical discussion, see, among others, Smith-Stark 1974, Silverstein 1976, Dixon 1979, Comrie 1989, Croft 1990, Yamamoto 1999, and Enger \& Nesset 2011). In the Austronesian language Muna (Corbett 2000: 71), for instance, and many other languages, human entities trigger obligatory number agreement on the verb, whereas such agreement is blocked for inanimate nouns. In turn, non-human animate entities, which have an intermediary position within the hierarchy, are characterized by optional number agreement. 3 According to Corbett's definition, subgenders are "agreement classes that control minimally different sets of agreement, that is, agreements differing for at most a small proportion of the morphosyntactic forms of any of the agreement targets". In the Slavic languages taken as a whole, this small proportion of different targets corresponds to the paradigmatic opposition between a nominative-accusative syncretism for inanimates and a genitive-accusative syncretism for animates. 
on extramorphological grounds (see Baerman, Brown \& Corbett 2010, 2015; for other, though related, definitions, see Stump \& Finkel 2013: 9 and passim). ${ }^{4}$ The principal focus here will be on the interaction of animacy and gender in relation to morphological complexity. As gender itself is often considered a rather conspicuous element of structural complexity (Audring 2014), the usual intricacies of its assignment and morphological expression should not be deemed particularly surprising. Inflection in turn can add complexity to the system, both in substance and in structural patterns, insofar as some morphological distinctions are not synchronically derivable from semantically motivated oppositions. Thus allomorphy (also with regard to gender) may be conceived as the main incarnation of morphological complexity or unpredictability.

In order to show the effects of animacy in inflection, which appear to reduce or constrain the morphological complexity of inflectional paradigms, we will rely chiefly on data from Slavic languages and some Greek dialects formerly spoken in Anatolia (a group of dialects from Asia Minor usually called Cappadocian). Sections 2 and 3, respectively, will discuss some of the diachronic developments that affected the expression of gender and animacy in Slavic and Cappadocian Greek. Thereafter, Section 4 will present the evolution of gender in Chamorro, an Austronesian language that has adopted some gender distinctions under the strong influence of Spanish. As a mirror image of the process of gender loss undergone by Cappadocian Greek, the Chamorro evidence likewise points to a semantic criterion (in this case, natural gender or biological sex) as the guiding factor in morphological changes associated with the expression of gender. Section 5 offers a brief summary of the main findings of the present study as well as further discussion concerning some morphological consequences of the emergence of grammatical animacy. Lastly, in Section 6 the most important conclusions will be drawn regarding the relationship between both animacy and natural gender, on the one hand, and the reduction of morphological complexity, on the other.

\section{The role of animacy in the reduction of allomorphy}

In the Slavic languages, the grammatical distinction between animate and inanimate nouns is primarily an inflectional one. Animacy is reflected in a specific pattern of case syncretism (genitive-accusative), as opposed to the nominative-accusative syncretism characteristic of inanimate nouns. This distinction applies primarily to masculine singular nouns. Moreover, the conditions and the extent to which animacy is further realized in different inflectional classes vary depending on the language: the East Slavic languages (Russian, Belarusian, and Ukrainian) extend the morphological distinction to all genders in the plural (within certain limits in Ukrainian), whereas in South Slavic (Slovene, Serbian, Croatian) and Czech there is no spread of animacy beyond the singular paradigm (and, of course, the masculine gender). In the remaining West Slavic languages (Polish, Sorbian, and Slovak, excluding Czech), the animacy-based pattern of syncretism is reflected also in the plural (but among masculine nouns only, with even further differentiation between human and non-human animate reference in such systems as Polish).

In Table 2 we present the distribution of inflectional classes in Late Proto-Slavic, the system from which all the modern languages derive. There were 6 classes in Late Proto-Slavic (even 7, according to some descriptions), which can be established on the basis of the stem suffix used in each case (see Table 2, from Schenker 1995: 124, Igartua 2005: 365-374, Olander 2015: 69-75):

\footnotetext{
4 Stump and Finkel (2013: 9) regard the complexity of an inflection-class system as "the extent to which it inhibits motivated inferences about a lexeme's full paradigm of forms from subsets of these forms", a definition that rests on other notions such as that of 'principal parts', the term used to refer to those paradigmatic forms on the basis of which speakers can predict other word forms of the same lexeme (see also Ackerman, Blevins \& Malouf 2009: 62, 69-70, Ackerman \& Malouf 2013: 437).
} 
Table 2. Late Proto-Slavic inflectional classes (singular only)

\begin{tabular}{|c|c|c|c|c|c|c|}
\hline & \multicolumn{5}{|c|}{ Vocalic stems } & \multirow[t]{2}{*}{ Consonant stems } \\
\hline & $*_{O}$ & ${ }^{\star} u-$ & $\star_{i-}$ & $\star^{\star} \bar{a}-$ & ${ }^{\star} \bar{u}-$ & \\
\hline NOM & $-b,-o$ & $-b$ & $-b$ & $-a$ & $-y$ & $-y,-o,-i,-e$ \\
\hline ACC & $-b$ & $-b$ & $-b$ & $-\tilde{o}$ & $-b v b$ & $-b,-o,-e$ \\
\hline GEN & $-a$ & $-u$ & $-i$ & $-y$ & -ъve & $-e$ \\
\hline DAT & $-u$ & -ovi & $-i$ & $-\check{e}$ & $-\mathrm{b} v i$ & $-i$ \\
\hline INS & $-o m b$ & $-\mathrm{b} m b$ & $-b m b$ & $-o j \tilde{o}$ & $-ъ v b j \tilde{o}$ & $-b m b,-b j \tilde{o}$ \\
\hline LOC & $-\check{e}$ & $-u$ & $-i$ & $-\check{e}$ & -ъve & $-e$ \\
\hline
\end{tabular}

Note: in * $i$-stems there is a difference in the instrumental case between masculine and feminine genders. In this table, only the masculine is represented (feminine counterpart: - bjō). Despite minor differences, the ${ }^{\star} \bar{u}$-stems could be considered a subclass of the consonant stems.

Over time these six classes were reduced to three or four in most of the Slavic languages (see Table 3 for a Russian example, after Corbett 1982: 216). In some languages (like Upper Sorbian and Cassubian), the noun system was further reduced to just two main (macro)classes, one for masculine and neuter nouns, and the other for feminine nouns (for the term macroclass, see Carstairs-McCarthy 1986, 1987). The main factor guiding this process of morphological reorganization seems to have been grammatical gender. Older inflectional classes were fused or simply absorbed by other, more productive classes on the basis of a shared value of gender (masculine, feminine, or neuter).

Table 3. Russian inflectional classes (singular only)

\begin{tabular}{lllll}
\hline & I & II & III & IV \\
\hline NOM & zakon & škol-a & kost' & pis'm-o \\
ACC & zakon & škol-u & kost' & pis'm-o \\
GEN & zakon-a & škol-y & kost-i & pis'm-a \\
DAT & zakon-u & škol-e & kost-i & pis'm-u \\
INS & zakon-om & škol-oj & kost-ju & pis'm-om \\
LOC & zakon-e & škol-e & kost-i & pis'm-e \\
& 'law' & 'school' & 'bone' & 'letter'
\end{tabular}

Note: according to some descriptions, classes I and IV can even be subsumed under a single inflectional macroclass, in which minimal morphological differences (limited to the form of the NOM-ACC.SG) are motivated by gender.

In paradigms in which morphological fusion occurred in historical systems, there was an (over)abundance of inflectional morphemes whose distribution can be defined as idiosyncratic or at least not clearly motivated (see Table 4, based on Townsend \& Janda 1996: 148ff. and Igartua 2005: 457-459, for the development of ${ }^{\star} O-$ and ${ }^{\star} u$-stems in Late Proto-Slavic and earlier stages of historical systems, and compare it with the situation reflected in Table 2, which shows almost no allomorphy in ${ }^{\star} O$ - and ${ }^{\star} u$-stems).

Table 4. Fusion of ${ }^{*} o$ - and ${ }^{*} u$-stems in Late Proto-Slavic and earlier stages of the development of Slavic languages

\begin{tabular}{|c|c|c|}
\hline \multicolumn{3}{|c|}{ New unified paradigm with allomorphs } \\
\hline & SG & $\mathrm{PL}$ \\
\hline NOM & $-b$ & $-i$, -ove \\
\hline $\mathrm{ACC}$ & $-b,-a$ & $-y$ \\
\hline GEN & $-a,-u$ & $-b,-o v b$ \\
\hline DAT & $-u,-o v i$ & $-o m b,-b m b$ \\
\hline INS & -omb, - -bmb & $-y,-ъ m i$ \\
\hline LOC & $-\check{e},-u$ & -е̌xъ, -ъxъ \\
\hline
\end{tabular}


With the exception of the nominative singular and the accusative plural cases, in the new paradigm for masculine nouns there were at least two markers for each morphosyntactic value (case). At this historical point (Late Proto-Slavic and the first attested stages of evolution of the Slavic languages) we observe the rise of animacy, represented by the ending - $a$ in the accusative singular in Table 4 above (originally a genitive morpheme belonging to the ${ }^{\star} O$-stem paradigm that, subsequently, spread to other inflectional classes). As described above, grammatical animacy in the Slavic languages rests primarily on a minimal paradigmatic difference, with masculine animate nouns showing genitive-accusative syncretism (in the singular), whereas the rest are characterized by nominative-accusative syncretism: cf. Old Church Slavonic NOM.SG bratı vs. GEN-ACC.SG brata 'brother', on the one hand, and NOM-ACC.SG světı vs. GEN.sG světa 'light', on the other (see Table 5, shaded cells indicate different syncretism patterns):

Table 5. Old Church Slavonic * $o$-stems

\begin{tabular}{c|l|l}
\hline NOM.SG & bratb & světb \\
ACC.SG & brata & světb \\
GEN.SG & brata & světa \\
& 'brother' & 'light' \\
\hline
\end{tabular}

This subgender distinction was originally restricted to some masculine stems ( ${ }^{\star} o_{-}^{-},{ }^{\star} u-$, and ${ }^{\star} i$-stems). In any event, besides this difference in syncretism patterns, animacy was also expressed historically by other means. Some endings became specific markers of animacy (or humanness) in several languages, such as -ovi/-evi in the dative (and locative) singular and -ove/-eve or - $i$ in the nominative plural, as is the case in Czech and Slovak (see Table 6, in which shaded cells indicate the differing patterns of syncretism in animate and inanimate nouns) and at least partially in Polish. To put it another way, an excess of morphological markers within this inflectional class was partly restricted through semantic specialization of a subset of morphemes (other features also play a role, but animacy seems to have been the main factor reorganizing these inflectional paradigms). In this fashion, we would assert that animacy constrained a process of increasing complexity in some inflectional paradigms.

Table 6. Masculine paradigms in Czech and Slovak

\begin{tabular}{|c|c|c|c|c|}
\hline & \multicolumn{2}{|c|}{ Czech } & \multicolumn{2}{|c|}{ Slovak } \\
\hline & ANIM & INANIM & ANIM & INANIM \\
\hline NOM.SG & chlap & hrad & chlap & $d u b$ \\
\hline ACC.SG & chlap-a & hrad & chlap-a & $d u b$ \\
\hline GEN.SG & chlap-a & hrad-u & chlap-a & $d u b-a$ \\
\hline DAT.SG & chlap-ovi, -u & hrad-u & chlap-ovi & $d u b-u$ \\
\hline INS.SG & chlap-em & hrad-em & chlap-om & dub-om \\
\hline LOC.SG & chlap-ovi, -u & hrad-ě & chlap-ovi & $d u b-e$ \\
\hline \multirow[t]{2}{*}{ NOM.PL } & chlap-i & hrad-y & chlap-i & $d u b-y$ \\
\hline & 'fellow' & 'castle' & 'fellow' & ‘oak' \\
\hline
\end{tabular}

Note: In Czech, there is some variation in dative and locative between -ovi and - $u$ in animate nouns, but usually these cases differ from their inanimate counterparts; in Slovak, the opposition is even clearer.

In Janda (1996a) this kind of innovation was interpreted as the recycling of relic forms (which would be exaptation, in Lass' (1990) terms). The endings of the ancient * $u$-stems (but not only these) served as source material for new semantic and grammatical distinctions in several Slavic languages. Furthermore, the distribution of those markers was not accidental: according to Janda (1996b: 333), the old * $u$-stem endings 
were recruited for "the most unmarked instances of the cases where they appear". Since the nominative and the dative typically involve agents and experiencers, it was quite natural to use the recycled markers for animates (see also Enger \& Nesset 2011: 202). In other cases, the presence of the ${ }^{\star} u$-stem suffixes was not so unambiguous, although there was still some tendency to associate them with inanimate nouns (as with the ending $-u$ in the genitive singular and locative singular; for the so-called second genitive and second locative in Russian, see Brown 2007, Corbett 2008). In these circumstances, the feature of animacy provided, from our current perspective, a straightforward criterion for reorganizing the inflectional material in a particular direction: it crucially gave a semantically transparent motivation for certain formal differences, thereby restricting the morphological complexity of the inflectional system. ${ }^{5}$ Experimental studies like that of Vihman, Nelson and Kirby (2018) show that the reorganization of noun classes is one of the main ways in which animacy-related structure can emerge in languages.

The influence of animacy on noun declension and its overall strength as a semantic feature can be clearly observed in cases in which animacy has historically overcome certain formal limits. It was mentioned above that grammatical animacy is not reflected in feminine nouns (except for the plural paradigm in the East Slavic languages and some very specific dialectal developments). Nor does it characterize the declension of ${ }^{\star} \bar{a}$-stem masculine nouns like Russ. deduška 'grandfather' or Cz. sluha 'servant', which behave morphologically just like the ${ }^{\star} \bar{a}$-stem feminine nouns (i.e. they have a non-syncretic accusative in -u). Nevertheless, as can be seen in Table 7 below (Short 1993: 543), in Slovak the paradigm of sluha has evolved a genitive-accusative syncretism in spite of the fact that there was no preexisting nominativeaccusative syncretism within this paradigm. Shaded cells indicate the different patterns of case syncretism in feminine and masculine gender within this inflectional class.

Table 7. Feminine and masculine paradigms of ${ }^{*} \bar{a}$-stems in Slovak

\begin{tabular}{|c|c|c|c|c|}
\hline & \multicolumn{2}{|c|}{ SINGULAR } & \multicolumn{2}{|c|}{ PLURAL } \\
\hline & FEM & MASC & ANIM & INANIM \\
\hline NOM.SG & žen- $a$ & sluh-a & žen-y & sluh-ovia \\
\hline ACC.SG & žen-u & sluh-u & žen-y & sluh-ov \\
\hline GEN.SG & žen-y & sluh-u & žien & sluh-ov \\
\hline DAT.SG & žen-e & sluh-ovi & žen-ám & sluh-om \\
\hline INS.SG & žen-ou & sluh-om & žen-ami & sluh-ami \\
\hline \multirow[t]{2}{*}{ LOC.SG } & žen-e & sluh-ovi & žen-ách & sluh-och \\
\hline & ‘woman' & 'servant' & 'women' & 'servants' \\
\hline
\end{tabular}

This special innovation, which arises by analogy with the paradigmatic structure of other masculine nouns, nicely illustrates how animacy can find its way into the nominal declension even if preconditions for its emergence are lacking. Diachronically, the choice of the morpheme for the new genitive-accusative syncretism is also interesting, because it contrasts sharply with the general replacement of the old accusative (which was syncretic with the nominative form) by the genitive. In this Slovak innovation we find the opposite, namely that the accusative case replaces the genitive form (the older sluhi).

5 As pointed out by one anonymous reviewer, the evolution of noun inflection in Czech and Slovak is similarly paralleled by the development of the 'weak' masculine noun class in German, characterized by the use of the ending -en in all cases except the nominative singular (cf. Löwe 'lion' and Löwen for the accusative, genitive, and dative). This class has tended to be associated with animacy (see Wurzel 1998: 241 ff.). Historically, inanimate nouns that formerly belonged to this class have been shifted to other classes. 


\section{The effects of animacy in processes of gender decline}

Before analysing some aspects of the evolution of the Cappadocian Greek declension, a few general remarks are in order. As described by Janse (2009: 37), "Cappadocian is a Greek-Turkish mixed language ${ }^{6}$ formerly spoken by Greek Orthodox Christians in Cappadocia in the Turkish region of Central Anatolia until the population exchange between Greece and Turkey in accordance with the 1923 Treaty of Lausanne”. It was generally believed that Cappadocian died out in the 1960s, until it was discovered that Cappadocian is still spoken as a first language by several hundred people in Northern and Central Greece. According to the present state of our knowledge, the dialect of Misti is the only Cappadocian dialect that is still used as a vernacular, albeit mostly by middle-aged and elderly people.

One of the numerous salient properties of Cappadocian Greek is the lack of gender. Evidence for this is understood as the absence of agreement or co-variation between nouns-controllers and target forms. Gender agreement was lost under the pressure of contact from Turkish-speaking communities, according to the traditional account (Dawkins 1916: 116, 125), although internal factors (the evolution of the noun system in these dialects) may have also played a part in this (Karatsareas 2009, cf. Dawkins 1916: 116, Hovdhaugen 1976: 144). In contrast, Standard Modern Greek (and other dialects) retain the category of grammatical gender, and some of the historical changes undergone by Greek noun declension are best explained precisely in connection with the reorganizing effect of gender (see Morpurgo Davies 1968 and Coker 2009, for example). Table 8 below illustrates the difference in agreement between Standard Modern Greek and a Cappadocian variety (that from Ulağáç, see Karatsareas 2009: 197, with references), which lacks gender distinctions.

Table 8. Ulağáç and Standard Modern Greek (SMG) noun phrases compared.

\begin{tabular}{llll}
\hline & Ulağáç & SMG & Gloss \\
\hline SG. & do kalon do andra & o kalos anđras & 'the good man (M)' \\
& do kalon do neka & i kali jineka & 'the good woman (F)' \\
& do kalon do pei & to kalo peđi & 'the good child (N)' \\
PL. & da kalan da andres & i kali anđres & 'the good men (M)' \\
& da kalan da nekes & i kales jinekes & 'the good women (F)' \\
& da kalan da peija & ta kala peđja & 'the good children (N)'
\end{tabular}

The tendency towards the loss of gender agreement was accompanied in several Cappadocian Greek varieties by a (simultaneous?) process of morphological reclassification of nouns into animate and inanimate. As pointed out by Janse (2004: 7), "ancient masculine nouns in -os are characterized by what could be called an animacy split: nouns referring to animates are treated as masculine nouns, whereas nouns referring to inanimates are treated as neuter nouns". That is, an animacy-based distinction arose which transformed the inherited distribution of nouns into gender classes, at least as far as the relationship between the former masculine and neuter genders is concerned. The new distinction was chiefly declensional (compare below Tables 9 and 10), as it had only limited repercussions for agreement: animate nouns take the masculine article except in the nominative case, and inanimate nouns take the neuter article in all cases (Janse 2004: 5).

In Northeast Cappadocian and at Axó (Central Cappadocian), the declension of masculine-animate (specifically human, we could add) nouns in -os is as given in Table 9 (á日ropos 'man'), after Janse (2004: 7):

6 Be that as it may, not all scholars would agree with this characterization of Cappadocian Greek as a mixed language, since there is little doubt as to the genetic affiliation of those dialects (they are obviously Greek, even if deeply influenced by Turkish). 
Table 9. Animate declension in Northeast Cappadocian and at Axó

\begin{tabular}{|c|c|c|c|}
\hline & & SG & PL \\
\hline NOM & & átropos & aөróp \\
\hline \multirow[t]{2}{*}{ ACC } & INDEF & á⿴ropos & 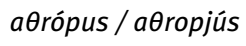 \\
\hline & DEF & 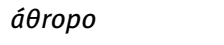 & \\
\hline GEN & & 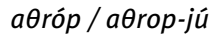 & \\
\hline
\end{tabular}

Notes: The difference between indefinite and definite forms is relevant only in the singular. There is no distinction in the genitive between the singular and plural.

In other varieties (Northwest Cappadocian and Mistí), there is no separate form for the accusative plural (NOM-ACC.PL a $a$ róp), see Table 10.

Table 10. Animate declension in Northwest Cappadocian and at Mistí

\begin{tabular}{|c|c|c|c|}
\hline & & SG & PL \\
\hline NOM & & áOropos & aөróp \\
\hline \multirow[t]{2}{*}{ ACC } & INDEF & áAropos & aөróp \\
\hline & DEF & áAropo & \\
\hline GEN & & 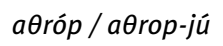 & \\
\hline
\end{tabular}

In North Cappadocian, the declension of neuter-inanimate nouns in -os differs in one respect from the declension of masculine-animate nouns: as illustrated in Table 11, there is again no separate form for the nominative plural, which is formally identical with the accusative plural (milos 'mill'), but the inflectional marker corresponds to that of the original accusative case, whereas in animate-masculine nouns the nominative-accusative syncretism is based on the form of the original nominative case (see the shaded cells in Table 10). In contrast to Cappadocian, Standard Modern Greek exhibits no morphological distinction between animate and inanimate nouns (both semantic classes have -or /-i/ in one of the masculine paradigms as the nominative plural ending, and -ovs /-us/ as the accusative plural marker).

Table 11. Inanimate declension in North Cappadocian

\begin{tabular}{|c|c|c|c|}
\hline & & SG & PL \\
\hline NOM & & mílos & milús \\
\hline \multirow[t]{2}{*}{ ACC } & INDEF & mílos & milús \\
\hline & DEF & mílo & \\
\hline GEN & & míl / mil-jú & \\
\hline
\end{tabular}

The difference between the two inflectional patterns represented in Tables 10 and 11 has been interpreted as a direct effect of the animacy feature (Janse 2004: 9):

since subjects are generally more animate than objects, it was the nominative that was generalized in the case of the masculine-animate nouns and the accusative in the case of the neuter-inanimate nouns. The question of why there should be syncretism in the first place is often explained in terms of markedness: the plural being marked as opposed to the singular, there is an overall tendency toward fewer subcategories of the plural.

Following Janse's account, the difference between the syncretic nominative-accusative plural of masculineanimate (in Northwest Cappadocian and at Mistí, see Table 10 above) vs. neuter-inanimate nouns can also be explained in terms of markedness: the unmarked case for animate nouns is the nominative, whereas the unmarked case for inanimate nouns is the accusative. The choice of the form to be generalized is thus based on the unmarked case in both instances. 
In these Cappadocian developments, animacy introduces a sort of order into a system that was organized around the feature of gender and that, subsequently, lost this feature (with known consequences for agreement), but not some of the inflectional differences formerly associated with gender and inflectional class. Animacy transformed the internal structure of the noun system: some masculine nouns (those with inanimate referents) came to be inflected like neuter nouns (as did some old feminine nouns too). They all created a new class of inanimate nouns as opposed to the class of animate ones.

A distant typological parallel to this process can be found in the transformation of the noun class system in some Bantu languages. In Lingala, Shaba Swahili and other Bantu languages (some of them creolized or true creoles), researchers identify a general tendency towards reduction in the morphological system of noun classes. Under these circumstances, grammatical agreement depending on class appurtenance tends to be replaced by formal distinctions based on animacy or humanness (Maho 1999: 127, see also Ortmann 1998: 67-69). Not only are animate nouns that belonged to inanimate classes brought into typically animate classes, as in Shaba Swahili (McWhorter 2007: 261), the whole agreement system is reorganized according to this simpler distinction between animate and inanimate, which manifests itself in the use of exclusive prefixes for animate reference (both in targets, as in Lingala, and in nouns-controllers, as in Lunda; see Maho 1999: 132-134). ${ }^{7}$ In contrast to Cappadocian, though, it seems that neither of these Bantu systems has lost gender altogether (perhaps with the exception of Kituba, which may represent a clear case of deflection, see Stucky 1978: 227-228, Dimmendaal 2011: 229) ${ }^{8}$.

\section{Female animacy or natural gender in replicated gender systems}

The Austronesian language Chamorro, spoken by about 47,000 people on Guam and in the Northern Mariana Islands, represents a rare example of a genderless language that, under the influence of other languages, has copied gender markers and developed what Stolz (2012) terms a 'marginal gender' system, which is mainly characterized by a limited impact on the agreement system. There are a few other similar cases among the world's languages, including Ilocano (Austronesian, Rubino 1997: 138-139), Ayacucho Quechua (cf. Aikhenvald 2000: 48), Indonesian (Tadmor 2007: 311-314), Tagalog (Stolz 2012: 98-100), and Basque (Hurch 1989: 24-25, Trask 2003: 137). These examples differ in the extent to which gender is reflected in agreement constructions, but many of them share the source of the new gender markers, which come from Spanish (the suffixes $-o$, masculine, and $-a$, feminine). As regards agreement, Chamorro is probably the system in which it has been extended the furthest.

According to Stolz (2012: 116), there are 300 pairs of sex-differentiated forms in Chamorro and now syntactic agreement has begun to reflect, at least partially, these distinctions (see 1, adapted from Stolz 2012: 124-125).

(1) a. Guaha dos na dichos-a-n palum-a

EXI two LINK faithful-F-LINK dove-F

'There were two loyal doves'

b. Banidos-u gi tutuhon si Masåla'

proud-M in beginning DEF.PN Masåla

'In the beginning, Masåla [i.e. the father] was proud'

7 The Bantu developments show that "the morphological discrimination of animacy, which is argued to be the most fundamental gender distinction, is perfectly stable also in gender systems that are otherwise subject to changes, most notably to reductions of the number of classes and internal reassignments" (Ortmann 1998: 69). Verkerk \& Di Garbo's (2017) recent research confirms the existence of a bias towards animacy-based restructuring of gender systems in several Bantu languages. In contrast to these languages, in which animacy or humanness was already present in the noun class system since Proto-Bantu times (Herbert 1985: 175, 178), in Cappadocian Greek animacy appears to emerge as a new grammatical category concomitantly with the loss of gender distinctions.

8 Animacy also appears to guide several processes of inflection loss in Akan, a Central Tano language (Niger-Congo) in which former affixes are either lost or reorganized on the basis of a semantic distinction among human, non-human and inanimate nouns (cf. Osam 1993 [1996]). 
While the suffix - $a$ in Chamorro (as in 1a) indicates the female sex when reference is made to human (or sexdifferentiable) beings, the suffix $-o /-u$ and final consonants are used in adjectives referring to nouns that denote either the male sex or inanimate concepts (Stolz 2012: 125). ${ }^{9}$ Yet apparently this is so only in a "small circumscribed sub-area of the lexicon and of the grammatical system" of the language (almost exclusively affecting loanwords from Spanish; the formal variation in this subclass of adjectives is barely reflected in the reference grammar by Topping 1973). This is why, to account for these restrictions, Stolz (2012: 128) believes it appropriate to consider the Chamorro case an instance of marginal gender.

But what specifically interests us here is the new distribution that the borrowed gender suffixes show in Chamorro as compared to the situation in the donor language. As indicated above, the feminine suffix $-a$ is exclusively used to refer to females, while target forms in $-o$ agree with nouns denoting male sex or inanimate concepts, as can be seen in (2), from Stolz (2012: 125):

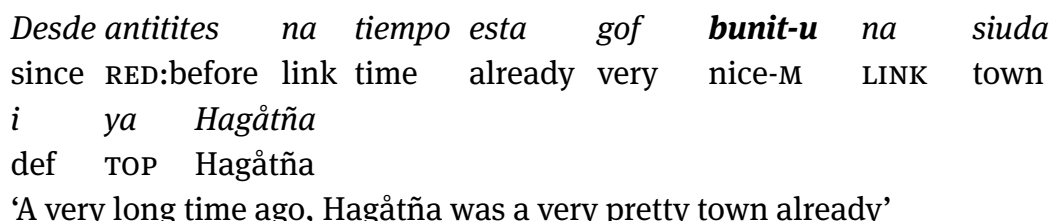

The noun siuda is clearly a loan from Spanish (< ciudad 'city, town'). In Spanish, the noun is assigned feminine gender (la ciudad 'the city'). But in Chamorro this assignment is obviously lost on semantic grounds, since the noun does not denote any sex-differentiable entity: hence the form bunit-u (and not bunit-a) referring to the noun siuda (in the case of palao'an 'woman' or sotterita 'adolescent girl', for instance, the agreeing adjective regularly takes the form bunita). ${ }^{10}$ Thus, together with the replication of gender markers in some borrowed words (first of all, adjectives), Chamorro has reorganized the original agreement system in accordance with a semantically rather transparent criterion that separates nouns into two big classes, namely a human feminine class and a large residue, in which human masculine and the rest of nouns are included. As described by Stolz (2012: 129), after having replicated some of the Spanish gender constructions, Chamorro has been following "the same evolutionary path as other semantically based bi-partite gender systems in which animacy is the decisive factor" (see also Corbett 1991: 14-32).

\section{Discussion}

The case studies presented in the preceding sections demonstrate three slightly different ways in which animacy and natural gender can affect morphological distinctions fully or partly associated with the expression of grammatical gender.

As summarized in Table 12 below, animacy and natural gender can be held to be responsible for several developments resulting in a significant decrease in morphological complexity (or in certain restrictions upon it). In the Slavic languages surveyed in Section 2, especially in Czech and Slovak, the overabundant formal distinctions in noun declension, at least some of which seem to have been at some point functionally unmotivated, have been given grammatical sense when animacy emerged as a morphologically-expressed semantic category. The innovative changes associated with the decline of gender in Cappadocian Greek

9 The distinction between genders is thus based on semantic criteria, with sex being arguably the decisive factor. Given that this is one of the common pathways in the organization and restructuring of gender systems, a line of research worth pursuing might be how and why borrowed marginal gender is usually quite restricted in its possibilities of spreading across the lexicon and the agreement system of languages (and even whether this is just a matter of time).

10 To be sure, not all borrowed adjectives behave the same way in this respect. According to Stolz's analysis, there is a class of gender-insensitive words in Chamorro that includes such adjectives as enkantåo 'magical, mysterious' (< Spanish encantad$o /-a$ 'enchanted, charmed'), which appear to have an invariable (originally masculine) form, and, accordingly, when applied to nouns denoting females they display this 'masculine' morphology. 
show, in turn, what can be viewed as a variant of the process represented in the Slavic languages: in the Cappadocian case, the decay of grammatical gender paved the way for a reinterpretation of residual formal oppositions on the basis of animacy, usually the main building block (Dahl 2000b: 579-580) of gender, including natural gender (for a well-researched development along these lines in the history of English, see, for example, Kastovsky 2000, McWhorter 2002). In any case, the circumstances under which this change took place are different enough to justify treating this development as a distinct manifestation of complexity decrease. Finally, borrowed gender markers in Chamorro, which introduced into its grammatical system a degree of morphological complexity unknown until the time of contact with Spanish, have been subject to a reassignment process in which female animacy was the key factor.

Table 12. Effects of animacy and natural gender on morphological complexity

\begin{tabular}{ll}
\hline Mechanism & Example \\
\hline 1. Reduction of inflectional allomorphy & Slavic languages (esp. Czech, Slovak) \\
2. Reorganization of residual formal distinctions & Cappadocian Greek (parallels in Bantu) \\
3. Reinterpretation of gender assignment rules & Chamorro \\
\hline
\end{tabular}

It is worth noting that Mechanisms 2 and 3 represent reverse situations. Within the context of the former, we are dealing with a process whereby formal distinctions are disappearing (even if some of them are still preserved, and this is precisely the precondition for the actuation of animacy). In the latter case, formal distinctions are introduced anew into a system that was devoid of a feature like gender. The morphological complexity arising in both situations, albeit due to opposite reasons, turns out to be limited along quite similar lines. Specifically in Mechanism 3, the increase in complexity is constrained in the sense that, were it not for a sex-based distinction (female animacy), the degree of complexity that might have arisen could have been higher. These innovations, as well as those covered by Mechanism 1, demonstrate the determinant function of animacy and natural gender in the reduction of morphological complexity. Far from being typologically unusual, the diachronic developments studied here are in line with the widespread presence of animacy-based gender or noun categorization systems in the world's languages as well as with the not uncommon transition from grammatical to natural (sex- or animacy-based) gender, of which English is a widely recognized example.

Of course, there may be other ways of looking at these phenomena. One possible way is reinterpreting the above typology as a classification of the pathways that lead animacy (and natural gender) to break into a grammatical system. ${ }^{11}$ From this perspective, animacy can become part of the grammar through (i) differentiation of inflectional classes (Czech, Slovak), (ii) emerging subgenders (the majority of Slavic languages), which can in turn be considered instances of (iii) differential object marking (reflected also in Cappadocian Greek). Natural or sex-based gender in processes of agreement replication can emerge as a consequence of rule reassignment. This is a complementary view to the perspective taken up in this study.

Thus far we have analysed diachronic processes in which morphological complexity is gradually reduced or constrained through the association of certain inflectional distinctions, which historically have lost functional weight, with the feature of animacy (or with sex-based gender). But animacy seems to be also at the basis of creating new distinctions. Even though the introduction of formal differences is in this case semantically motivated (in the sense that animacy does not add complexity to the system in terms of the unpredictability of certain morphological variations), it is nonetheless instructive to see how animacy-induced innovations are also constrained in a particular way. A case in point is that of the Slavic languages, in which the rise of animacy brings no new morphological material; it just introduces a new pattern of syncretism (between the accusative and the genitive cases) characteristic of animate nouns (see again Table 5 above). A more complex development is found in Andi, a Northeast Caucasian language spoken in Southern Daghestan whose dialectal differences with regard to the nominal system

11 Here we elaborate on an insightful suggestion by one anonymous reviewer. 
are discussed in detail in Corbett (1991: 198-200). Several dialects of Andi have introduced new animacybased distinctions into the nominal system, giving rise to nominal subclasses characterized as non-human animates or even insects. But again, in the development of these subclasses no new morphological material is involved; the different Andi dialects just make use of the existing inflectional markers (for the singular and the plural), recombining them in such a way as to create distinctive syncretism patterns associated with each of the new animacy-based subclasses. Of course, since these new syncretism patterns rest upon clearly recognizable referential properties, even though the nominal structure as a whole seems to gain in complexity, they do not add unpredictability to the morphological system (which is the main definitional trait of inflectional complexity, as introduced in Section 1 above). This is consistent with experimental results such as those presented in Vihman, Nelson \& Kirby (2018), who show that structural and formal complexity can be retained - specifically "if it is conditioned by something that learners can easily pick up". Animacy furnishes a semantic and cognitive basis that allows for retention and even creation of certain formal distinctions but, crucially, without causing additional complexity to the system.

\section{Concluding remarks}

In some languages analysed in this paper, animacy seems to have provided a solid semantic criterion for reorganizing the inflectional material inherited from older stages of evolution of these languages. In several cases, morphological markers get rid of the grammatical (or other) motivation they previously had. This process, further obscured by phonological developments, led to an increase in the 'gratuitous' morphological complexity of inflectional systems (as Baerman, Brown \& Corbett 2010 call it). Under these circumstances, animacy introduces a criterion that substantiates certain morphological differences, making them predictable on a fairly semantic basis and thereby constraining the morphological complexity of the system. Even in the case of a vanishing category like that of gender in Cappadocian Greek, some of the still remaining formal distinctions receive a functional motivation on the basis of animacy.

In newly acquired - via borrowing - gender systems, however marginal they may be, the formal criteria for gender assignment that at least partly characterized the system of the donor language tend to be historically replaced in the recipient language by an unequivocally semantic criterion dependent on biological sex (what we have called female animacy), as was the case in the Chamorro developments examined in this article.

To sum up, animacy and natural gender emerge as robust semantic features guiding several instances of morphological (specifically, morpho-semantic) restructuring that, regardless of the different circumstances under which they happen to evolve, can result in a significant reduction of morphological complexity (or, alternatively, in several constraints thereon). Corbett (2000: 265-271) shows that the Animacy Hierarchy is a strong predictor of language change in the realm of number (see also Enger \& Nesset 2011: 198). Likewise, the diachronic evidence discussed in this paper strongly suggests that animacy (together with natural gender) can be a determinant factor in language change.

Acknowledgments: The research for this article has been made possible by a grant from the Spanish Ministry of the Economy and Competitiveness (FFI2014-57260-P). Support given by the research group on linguistics (UFI11/14) at the University of the Basque Country (UPV/EHU) and the research group on historical linguistics (IT698-13) funded by the Basque Government is also gratefully acknowledged. We also wish to thank the audience at the $50^{\text {th }}$ Annual Meeting of the Societas Linguistica Europaea (held in Zurich, 10-13 September 2017), and especially Livio Gaeta, Spike Gildea and Johanna Nichols for useful comments and suggestions on the ideas and proposals developed in this paper. Special thanks are due to the guest editors of this issue as well as to two anonymous reviewers, whose remarks have helped us refine and improve several aspects of our analysis. 


\section{Abbreviations}

\begin{tabular}{ll} 
ABL & ablative \\
ACC & accusative \\
ALL & allative \\
ANIM & animate \\
DAT & dative \\
DEF & definite (article) \\
ERG & ergative \\
EXI & existential \\
DEST & destinative \\
F & feminine \\
GEN & genitive \\
INANIM & inanimate \\
INDEF & indefinite \\
INS & instrumental \\
LINK & linking particle \\
LOC & locative \\
M & masculine \\
N & neuter, noun \\
NOM & nominative \\
NP & noun phrase \\
PL & plural \\
PN & proper noun marker \\
RED & reduplication \\
SG & singular \\
TOP & toponym marker \\
& \\
\hline
\end{tabular}

\section{References}

Ackerman, Farrell, James P. Blevins \& Robert Malouf. 2009. Parts and wholes: Implicative patterns in inflectional paradigms. In James P. Blevins \& Juliette Blevins (eds.), Analogy in grammar: Form and acquisition, 54-82. Oxford: Oxford University Press.

Ackerman, Farrell \& Robert Malouf. 2013. Morphological organization: The low conditional entropy conjecture. Language 89(3). 429-464.

Aikhenvald, Alexandra Y. 2000. Classifiers. A typology of noun categorization devices. Oxford: Oxford University Press. Audring, Jenny. 2014. Gender as a complex feature. Language Sciences 43. 5-17.

Baerman, Matthew, Dunstan Brown \& Greville G. Corbett. 2010. Morphological complexity: A typological perspective. Manuscript. Surrey: University of Surrey. Online: http://webilc.ilc.cnr.it/ pirrelli/ESF_workshop/materiali/corbett/ Pisa\%20paper-15a.pdf (accessed 12 June 2017).

Baerman, Matthew, Dunstan Brown \& Greville G. Corbett (eds.). 2015. Understanding and measuring morphological complexity. Oxford: Oxford University Press.

Brown, Dunstan. 2007. Peripheral functions and overdifferentiation: The Russian second locative. Russian Linguistics 31(1). 61-76.

Carstairs-McCarthy, Andrew. 1986. Macroclasses and paradigm economy in German nouns. Zeitschrift für Phonetik, Sprachwissenschaft und Kommunikationsforschung 39(1). 3-11.

Carstairs-McCarthy, Andrew. 1987. Allomorphy in inflexion. London, New York \& Sydney: Croom Helm.

Coker, Amy. 2009. Analogical change and grammatical gender in ancient Greek. Journal of Greek Linguistics 9. 34-55.

Comrie, Bernard. 1989. Language universals and linguistic typology: Syntax and morphology. 2nd ed. Chicago: University of Chicago Press.

Corbett, Greville G. 1982. Gender in Russian: An account of gender specification and its relationship to declension. Russian Linguistics 6. 197-232.

Corbett, Greville G. 1991. Gender. Cambridge: Cambridge University Press.

Corbett, Greville G. 2000. Number. Cambridge: Cambridge University Press. 
Corbett, Greville G. 2008. Determining morphosyntactic feature values: The case of case. In Greville G. Corbett \& Michael Noonan (eds.), Case and grammatical relations: Studies in honor of Bernard Comrie, 1-34. Oxford: Oxford University Press.

Cristofaro, Sonia. 2013. The referential hierarchy: Reviewing the evidence in diachronic perspective. In Dik Bakker \& Martin Haspelmath (eds.), Languages across boundaries. Studies in memory of Anna Siewierska, 69-93. Berlin \& Boston: Walter de Gruyter.

Croft, William. 1990. Typology and universals. Cambridge: Cambridge University Press.

Dahl, Östen. 2000a. Animacy and the notion of semantic gender. In Barbara Unterbeck, Matti Rissanen, Terttu Nevalainen \& Mirja Saari (eds.), Gender in grammar and cognition. I: Approaches to gender (Trends in Linguistics 124), 99-115. Berlin \& New York: Walter de Gruyter.

Dahl, Östen. 2000b. Elementary gender distinctions. In Barbara Unterbeck, Matti Rissanen, Terttu Nevalainen \& Mirja Saari (eds.), Gender in grammar and cognition. II: Manifestations of gender (Trends in Linguistics 124), 577-593. Berlin \& New York: Walter de Gruyter.

Dahl, Östen \& Kari Fraurud. 1996. Animacy in grammar and discourse. In Thorstein Fretheim \& Jeanette K. Gundel (eds.), Reference and referent accessibility, 47-64. Amsterdam \& Philadelphia: John Benjamins.

Dawkins, Richard M. 1916. Modern Greek in Asia Minor: A study of the dialects of Silli, Cappadocia and Phárasa with grammars, texts, translations, and glossary. Cambridge: Cambridge University Press.

Dimmendaal, Gerrit J. 2011. Historical linguistics and the comparative study of African languages. Amsterdam \& Philadelphia: John Benjamins.

Dixon, R. M. W. 1979. Ergativity. Language 55(1). 55-138.

Enger, Hans-Olav \& Tore Nesset. 2011 Constraints in diachronic development: The Animacy Hierarchy and the Relevance Constraint. Language Typology and Universals - Sprachtypologie und Universalienforschung 4(3). 193-212.

Herbert, Robert K. 1985. Gender systems and semanticity: Two case histories from Bantu. In Jacek Fisiak (ed.), Historical semantics - Historical word formation, 171-197. Amsterdam: Mouton.

Hovdhaugen, Even. 1976. Some aspects of language contact in Anatolia. Working Papers in Linguistics (Oslo) 7/8. 142-160.

Hurch, Bernhard. 1989. Hispanisierung im Baskischen. In Norbert Boretzky, Werner Enninger \& Thomas Stolz (eds.), Vielfalt der Kontakte. Beiträge zum 5. Essener Kolloquium über 'Grammatikalisierung: Natürlichkeit und Systemökonomie’ vom 6-8.10.1988 an der Universität Essen, 11-35. Band I. Bochum: Brockmeyer.

Igartua, Iván. 2005. Origen y evolución de la flexión nominal eslava. Bilbao: UPV/EHU.

Igartua, Iván. 2009. Morphological effects of feminine animacy in $16^{\text {th }}$ century Sorbian. Zeitschrift für slavische Philologie 66/1. 61-74.

Igartua, Iván. 2015. Feminine animacy in the Slavic languages. Talk delivered at the $48^{\text {th }}$ Annual Meeting of the Societas Linguistica Europaea, Leiden, 4 September 2015.

Igartua, Iván \& Nerea Madariaga. 2018. The interplay of semantic and formal factors in Russian morphosyntax: Animate paucal constructions in direct object function. Russian Linguistics 42(1). 27-55.

Janda, Laura A. 1996a. Back from the brink: a study of how relic forms serve as source material for analogical extension. München: Lincom Europa.

Janda, Laura A. 1996b. Figure, ground, and animacy in Slavic declension. Slavic and East European Journal 40(2). 325-355.

Janse, Mark. 2004. Animacy, definiteness, and case in Cappadocian and other Asia Minor Greek dialects. Journal of Greek Linguistics 5. 3-26.

Janse, Mark. 2009. Greek-Turkish language contact in Asia Minor. Études helléniques / Hellenic Studies 17. $37-54$.

Karatsareas, Petros. 2009. The loss of grammatical gender in Cappadocian Greek. Transactions of the Philological Society 107. 196-230.

Kastovsky, Dieter. 2000. Inflectional classes, morphological restructuring, and the dissolution of Old English grammatical gender. In Barbara Unterbeck, Matti Rissanen, Terttu Nevalainen \& Mirja Saari (eds.), Gender in grammar and cognition. II: Manifestations of gender (Trends in Linguistics 124), 709-727. Berlin \& New York: Mouton de Gruyter.

Klenin, Emily R. 1983. Animacy in Russian: A new interpretation. Ohio: Slavica Publishers.

Kittilä, Seppo, Katja Västi \& Jussi Ylikoski (eds.). 2011. Case, animacy, and semantic roles (Typological Studies in Language 99). Amsterdam \& Philadelphia: John Benjamins.

Krys'ko, Vadim B. 1994. Razvitie kategorii oduševlënnosti v istorii russkogo jazyka [The rise of the category of animacy in the history of the Russian language]. Moscow: Lyceum.

Lakoff, George. 1987. Women, fire, and dangerous things: What categories reveal about the mind. Chicago: University of Chicago Press.

Lass, Roger. 1990. How to do things with junk: Exaptation in language evolution. Journal of Linguistics 26(1). 79-102.

Maho, Jouni. 1999. A comparative study of Bantu noun classes (Orientalia et Africana Gothoburgensia 13). Göteborg: Acta Universitatis Gothoburgensis.

Malchukov, Andrej L. 2008. Animacy and asymmetries in differential case marking. Lingua 118. 203-221.

McWhorter, John. 2002. What happened to English? Diachronica 9(2). 217-272.

McWhorter, John. 2007. Language interrupted. Signs of non-native acquisition in standard language grammars. Oxford: Oxford University Press. 
Mel' chuk, Igor A. 1980. Animacy in Russian cardinal numerals and adjectives as an inflectional category: A problem of agreement. Language 56(4). 797-811.

Mikaelian, Irina. 2013. Cardinal numeral constructions and the category of animacy in Russian. Russian Linguistics 37(1). 71-90.

Morpurgo Davies, Anna. 1968. Gender and the development of the Greek declensions. Transactions of the Philological Society 67(1). 12-36.

Olander, Thomas. 2015. Proto-Slavic inflectional morphology. A comparative handbook. Leiden \& Boston: Brill.

Ortmann, Albert. 1998. The role of + /-animate in inflection. In Ray Fabri, Albert Ortmann \& Teresa Parodi (eds.), Models of inflection, 60-84. Tübingen: Niemeyer.

Osam, Emmanuel Kweku. 1993 [1996]. Animacy distinctions in Akan grammar. Studies in the Linguistic Sciences 23(2). 153-164.

Rubino, Carl. 1997. A reference grammar of llocano. PhD thesis. University of California, Santa Barbara.

Santazilia, Ekaitz. 2013. Noun morphology. In Mikel Martínez-Areta (ed.), Basque and Proto-Basque: Language-internal and typological approaches to linguistic reconstruction, 223-281. Frankfurt am Main: Peter Lang.

Schenker, Alexander. 1995. The dawn of Slavic: An introduction to Slavic philology. New Haven \& London: Yale University Press.

Short, David. 1993. Slovak. In Bernard Comrie \& Greville G. Corbett (eds.), The Slavonic languages, 533-591. London: Routledge.

Silverstein, Michael. 1976. Hierarchy of features and ergativity. In R. M. W. Dixon (ed.), Grammatical categories in Australian languages, 112-171. Canberra: Australian National University.

Smith-Stark, Thomas Cedric. 1974. The plurality split. In Michael W. La Galy, Robert M. Fox \& Anthony Bruck (eds.), Papers from the tenth regional meeting, Chicago Linguistic Society, 657-671. Chicago: Chicago Linguistic Society.

Stolz, Thomas. 2012. Survival in a niche. On gender-copy in Chamorro (and sundry languages). In Martine Vanhove, Thomas Stolz, Aina Urdze \& Hitomi Otsuka (eds.), Morphologies in contact, 93-140. Berlin: Akademie Verlag.

Stucky, Susan U. 1978. How a noun class system may be lost: Evidence from Kituba (lingua franca Kikongo). Studies in the Linguistic Sciences 8(1). 216-233.

Stump, Gregory \& Raphael Finkel. 2013. Morphological typology. From word to paradigm. Cambridge: Cambridge University Press.

de Swart, Peter \& Helen de Hoop. 2018. Shifting animacy. Theoretical Linguistics 44(1-2). 1-23.

Tadmor, Uri. 2007. Grammatical borrowing in Indonesian. In Yaron Matras \& Jeanette Sakel (eds.), Grammatical borrowing in cross-linguistic perspective, 301-328. Berlin \& New York: Mouton de Gruyter.

Topping, Donald D. 1973. Chamorro reference grammar (with the assistance of Bernadita C. Dungca). Honolulu: The University Press of Hawaii.

Townsend, Charles E. \& Laura A. Janda. 1996. Common and comparative Slavic: Phonology and inflection with special attention to Russian, Polish, Czech, Serbo-Croatian, Bulgarian. Columbus (Ohio): Slavica Publishers.

Trask, Robert L. 2003. The noun phrase: Nouns, determiners and modifiers; pronouns and names. In José Ignacio Hualde \& Jon Ortiz de Urbina (eds.), A grammar of Basque (Mouton Grammar Library 26), 113-170. Berlin \& New York: Mouton de Gruyter.

Verkerk, Annemarie \& Francesca di Garbo. 2017. Correlates of restructuring in Bantu gender systems. Talk delivered at the $50^{\text {th }}$ Annual Meeting of the Societas Linguistica Europaea, Zurich, 12 September 2017.

Vihman, Virve-Anneli, Diane Nelson \& Simon Kirby. 2018. Animacy distinctions arise from iterated learning. Open Linguistics (special issue: Effects of animacy in grammar and cognition).

Wurzel, Wolfgang U. 1998. Drei Ebenen der Struktur von Flexionsparadigmen. In Ray Fabri, Albert Ortmann \& Teresa Parodi (eds.), Models of inflection, 225-243. Tübingen: Niemeyer.

Yamamoto, Mutsumi. 1999. Animacy and reference. A cognitive approach to corpus linguistics. Amsterdam \& Philadelphia: John Benjamins. 